\title{
食道癌治療選択に関する患者サイドの意識
}

\begin{tabular}{lllll}
\multicolumn{8}{c}{ 防衛医科大学校第 1 外科 } \\
市倉 & 隆 & 帖 地 憲太郎 \\
坂 本 直 & 望 月 & 英 隆
\end{tabular}

\section{Treatment Modalities for Esophageal Cancer from Patients' Viewpoint}

\author{
Takashi ICHIKURA, Kentaro CHOCHI, Susumu SAIGUSA, \\ Naoko SAKAMOTO and Hidetaka MOCHIZUKI
}

First Department of Surgery, National Defense Medical College

患者サイドからみた食道癌治療に対する意識を調べる目的で, 当科で食道癌に対し右開胸・開腹による根治切 除を受けた症例に対し, 仮想状況を設定して手術と化学放射線療法 (CRT) のいずれを選ぶかについてアンケー 卜調查を行った。45名中41名 (91\%) から回答が得られた。CRTにより癌が治る可能性が手術と同じと仮定した 場合, 手術を選ぶ, CRTを選ぶと回答したものは各々 $44 \%, 54 \%$ であった。CRTにより癌が治る可能性が手術よ

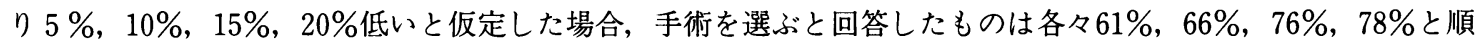
に上昇した。CRTを選ぶと回答したものにはT1症例が多かったが, 他の背景因子や術後の食事摄取, 身体愁訴と 回答との間に明らかな関連はみられなかった。Informed consentの際, 各治療の評価は医師サイドと患者サイド とで必ずしも一致しない可能性を念頭におくべきと考える。

索引用語：食道癌 (esophageal cancer), 化学放射線療法 (chemoradiotherapy), 手術 (surgical operation), アンケート調査 (questionnaire survey), quality of life

\section{緒言}

近年，癌の非手術的治療に対する社会的関心は 高く, 食道癌でも根治切除可能例に対する化学放 射線療法(CRT)の効果が注目されている1)。CRT と手術との長期予後に関する優劣は比較試験によ る評価が必要であるが, 治療中の苦痛や治療後の quality of life (QOL) 低下をどうとらえるかは個 人の主観によるところが大きい。今回, 患者サイ ドからみた食道癌治療に对する意識を調べる目的 で，当科で食道癌根治手術を受けた症例に対しア ンケート調查を行った。

\section{対象と方法}

1987〜2003年に食道癌に対し右開胸・開腹によ る根治切除が行われ, 無再発生存中の 45 名を対象 にアンケート調査を行った。アンケート用紙には 初めに下記のごとくCRTの説明を付した後,「も しあなたがいま食道癌と診断され, 内視鏡的な切 除は不可能, 手術によって治る可能性が $50 \%$ 前後 だとします。もし化学放射線療法によって癌が治 る可能性が手術と同じだとしたら，あなたはどの 治療を選びますか？」と質問した。さらに「もし 化学放射線療法によって癌が治る可能性が手術よ ク $5 \%$ 低いとしたら，あなたはどちらの治療を選 びますか？」, 同様に10\%，15\%，20\%低い場合に 
Table 1 Questionnaire concerning physical condition after esophagectomy for esophageal cancer

\begin{tabular}{|c|c|c|c|c|c|c|c|c|c|c|}
\hline \multirow{4}{*}{ Volume of each meal \# } & \multicolumn{5}{|c|}{ Surgery * } & \multicolumn{5}{|c|}{$\mathrm{CRT}^{*}$} \\
\hline & \multicolumn{5}{|c|}{$64 \pm 19 \%$} & \multicolumn{5}{|c|}{$62 \pm 18 \%$} \\
\hline & \multicolumn{5}{|c|}{ Choices } & \multicolumn{5}{|c|}{ Choices } \\
\hline & 1 & 2 & 3 & 4 & 5 & 1 & 2 & 3 & 4 & 5 \\
\hline Appetite ${ }^{a}$ & 44 & 50 & 6 & 0 & 0 & 48 & 48 & 0 & 5 & 0 \\
\hline Disturbance of food passage ${ }^{b}$ & 24 & 24 & 12 & 18 & 24 & 38 & 29 & 5 & 10 & 19 \\
\hline Vomiting ${ }^{b}$ & 72 & 17 & 0 & 11 & 0 & 90 & 0 & 10 & 0 & 0 \\
\hline Regurgitation ${ }^{\mathrm{b}}$ & 24 & 24 & 24 & 24 & 6 & 23 & 41 & 23 & 5 & 9 \\
\hline Aspiration ${ }^{b}$ & 28 & 28 & 33 & 11 & 0 & 41 & 27 & 14 & 9 & 9 \\
\hline Abdominal distension ${ }^{b}$ & 56 & 11 & 17 & 11 & 6 & 59 & 18 & 5 & 0 & 18 \\
\hline Abdominal pain ${ }^{\mathrm{b}}$ & 50 & 22 & 11 & 11 & 6 & 60 & 9 & 14 & 0 & 18 \\
\hline Diarrhea ${ }^{b}$ & 17 & 22 & 28 & 28 & 6 & 19 & 19 & 24 & 19 & 19 \\
\hline Early dumping syndrome ${ }^{b}$ & 83 & 11 & 0 & 0 & 6 & 62 & 5 & 10 & 5 & 19 \\
\hline Late dumping syndrome ${ }^{b}$ & 94 & 0 & 6 & 0 & 0 & 77 & 14 & 5 & 5 & 0 \\
\hline Pain of the chest wound ${ }^{b}$ & 56 & 17 & 11 & 11 & 6 & 59 & 5 & 14 & 14 & 9 \\
\hline Insufficient physical strength ${ }^{b}$ & 6 & 12 & 24 & 18 & 41 & 14 & 23 & 14 & 14 & 36 \\
\hline Return to work ${ }^{c}$ & 43 & 14 & 43 & & & 39 & 39 & 22 & & \\
\hline Face scale ${ }^{d}$ & 11 & 22 & 50 & 17 & 0 & 14 & 32 & 36 & 18 & 0 \\
\hline
\end{tabular}

* Patients who answered that they would choose surgery or chemoradiotherapy (CRT) if the expectancy for cure by CRT were almost equal to that by surgery.

\# Percentages compared with preoperatively, Mean \pm S.D

a 1 , excellent; 2 , good; 3 , fair; 4 , reduced; 5 , poor

b 1. none; 2 , once every one to two months; 3 , once or twice a month; 4 , two to three times a week; 5 , almost every day

c 1, yes; 2, changed his/her job to lighter work: 3 , quit working

d 1 (excellent) to 5 (poor)

Figures are percentages of patients for each choice.

ついて尋ねた。回答の選択肢は, (1)手術, (2)化学 放射線療法, (3)癌に対する積極的な治療はしない, の三者択一とした。

これらに加えて, 術後の食事攝取や愁訴, QOL に関する質問を設けた。質問項目および選択肢は

Table 1 に示した。

CRTの説明文：最近，食道癌の治療として手術 ではなく放射線と抗癌剂を組み合わせた治療(化 学放射線療法と呼びます) が行われることがあり ます。化学放射線療法は 2 力月程度かかることが 多く, 副作用も少なくありません。治療によって は生命が危険にさらされる可能性は手術よりは低 いもののゼロではありません。また長期間経過し た後に副作用が現れることもあります。しかし， 化学放射線療法では手術と違って食道や胃がその まま温存されますから，食事摂取についてはメリ ツトが大きいと考えられます。化学放射線療法が 効果があるかどうかは実際に治療してみないとわ かりません。現在のところ, 化学放射線療法が癌 を治すという意味で手術に匹敵するかどうかは不 明です。

\section{成 績}

41名（91\%）から回答が得られた。CRTにより 癌が治る可能性が手術と同じと仮定した場合, 手

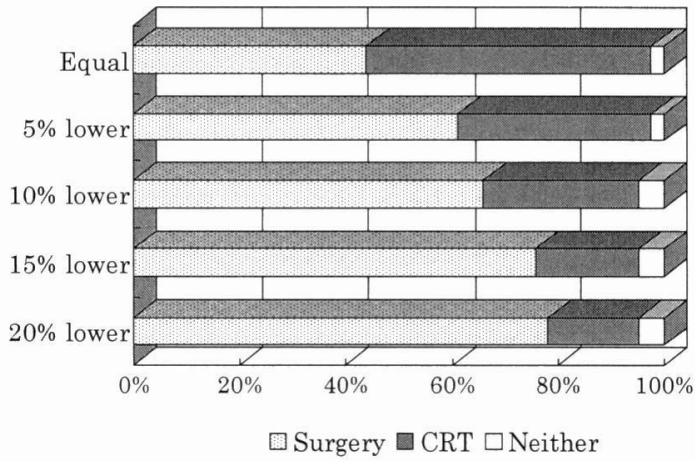

Fig. 1 Answer to the question "Which would you choose, surgery or chemoradiotherapy (CRT), if the expectancy for cure by the CRT were almost equal to, $5 \%$ lower, 10 lower, $15 \%$ lower, or $20 \%$ lower than that by surgery?"

術を選ぶ，CRTを選ぶと回答したものは各々 44 \%，54\%であった。CRTにより癌が治る可能性が 手術より $5 \%$ 低い，10\%低い，15\%低い，20\%低 いと仮定した場合，手術を選ぶと回答したものは 各々 $61 \% ， 66 \% ， 76 \% ， 78 \%$ と順に上昇した。一 方, CRTにより癌が治る可能性が手術より $20 \%$ 低 い場合でもCRTを選ぶとの回答が $17 \%$ にられ た。いずれの場合であっても積極的な治療を望ま ないとの回答が 1 名みられた (Fig. 1)。

CRTにより癌が治る可能性が手術と同じと仮 定した場合, 手術を選ぶと回答した群18例とCRT を選ぶと回答した群22例とで，背景因子および術 後の愁訴を比較した。手術を選ぶと回答した群の 3 例 (17\%), CRTを選ぶと回答した群の 2 例 ( 9 \%), 計 5 例が術前補助療法としてCRTを受けて いた。年齢や術後経過期間に両群の差はなかった。 女性 4 例のいずれもがCRTを選ぶと回答し, 結腸 再建 5 例中 4 例が手術を選ぶと回答したが有意差 はなかった。リンパ節転移の有無に両群の差はな かったが，CRTを選ぶと回答した群にT1症例が 有意に多かった（Table 2 ）。術後合併症や入院期 間に両群の差はなかった。食事摂取状況, 術後の 各愁訴, 体力, 職場復帰, 包括的QOL評価として のフェーススケールに関し, 手術を選ぶと回答し た群とCRTを選ぶと回答した群とで明らかな差 はみられなかった（Table 1)。 
Table 2 Background factors

\begin{tabular}{lcc}
\hline & $\begin{array}{c}\text { Surgery } \\
(\mathrm{n}=18)\end{array}$ & $\begin{array}{c}\mathrm{CRT}^{\star} \\
(\mathrm{n}=22)\end{array}$ \\
\hline Age $^{*}$ & $62.2 \pm 6.9(61)$ & $61.4 \pm 10.7(63.5)$ \\
Male/Female & $18 / 0$ & $18 / 4$ \\
Months after operation ${ }^{*}$ & $54.6 \pm 47.7(40.3)$ & $58.2 \pm 44.6(42.0)$ \\
Esophageal substitute (stomach/colon) & $14 / 4$ & $21 / 1$ \\
Route for reconstruction & $2 / 10 / 6$ & $2 / 12 / 8$ \\
(antesternal/retrosternal/mediastinal) & $4 / 5 / 6$ & $14 / 1 / 5$ \\
Tumor depth (T1/T2/T3·4) 9 & $10 / 8$ & $9 / 13$ \\
Nodal involvement $(+/ \cdot)$ & &
\end{tabular}

* Patients who answered that they would choose surgery or

chemoradiotherapy (CRT) if the expectancy for cure by CRT were almost equal to that by surgery.

\# Mean \pm S.D. (Median)

I $\mathrm{p}<0.05$, T1 vs. T2-4. Patients who received preoperative CRT (3 for

surgery group and 2 for CRT group) were excluded.

\section{考 察}

食道癌治療ガイドラインではT $1 \mathrm{a}, \mathrm{N}(+)$ から T3まで通常行われている治療として外科切除と 化学放射線療法とが併記されている2)。CRTでは 治療後のQOLは手術より良好と思われるが, 一方 で長期経過後の合併症も報告されている3)。両者 の優劣に関するエビデンスはなく，両治療法の利 点と欠点とを説明した上で患者自身に選択しても らうというのが多くの施設での現状であるが，説 明者の考え方が患者の意志決定を大きく左右する ものと思われる。

本研究は実際に手術を受けた患者が手術治療を どのように受け止めているかを知ることを目的と した。手術とCRTの遠隔子後が同等と仮定した場 合, CRTを選ぶとの回答が手術を選ぶとの回答を やや上回った。手術を選ぶと回答した群とCRTを 選択すると回答した群とで比較すると, 術後経過 期間, 年齢, 術後合併症などに両群間の差はなか ったが, 性別, 再建臟器, 腫瘍深達度で若干の相 違がみられた。すなわち女性や術前無症状例にお ける手術に対する負のイメージが，また胃切除後 症例における手術に対する容認性が推測される。 一方, CRTが手術に大きく優っていると思われる 術後愁訴や食事捸取状況については両群間で明ら かな差はみられなかった。

手術の遠隔予後が $5 \%$ でも優っていれば手術を 選ぶとする回答が $61 \%$ とCRTの $37 \%$ 上回った。 すなわち実際に経験した立場からみて, 手術とい
う modalityに対し，治療効果さ之確かならばそれ ほど否定的ではない患者が多かった点が注目され る。一方, CRTの長期成績が手術より $20 \%$ 少って いるとしてもCRTを選ぶとする回答が17\%にみ られたのも見逃せない点である。この手術に対し てかなり否定的な患者について検討したが, T1症 例が多いという以外に背景因子や術後の食事摂取 や身体愁訴に特徵はみられなかった（data not shown)。

すでに手術を選択し, 術後無再発生存中の症例 を対象としたことでアンケートの回答に一定のバ イアスが生じている可能性は否定できない。術後 経過期間の短い症例も含まれてはいるものの再発 死亡した症例は除かれていること，自身の受けた 治療を正当化したいという意志が働く可能性など についても考慮に入れて本結果を解釈する必要が あろう。

\section{結 語}

治療中の苦痛や治療後のQOL低下は受け止め 方の個人差が大きい。Informed consentを得る 際, 各治療の評価は医師サイドと患者サイドとで 必ずしも一致しない可能性を念頭におくべきと考 える。

\section{参考文献}

1) Hironaka S, Ohtsu A, Boku N, et al : Nonrandomized comparison between definitive chemoradiotherapy and radical surgery in patients with $\mathrm{T}(2-3) \mathrm{N}$ (any) $\mathrm{M}(0)$ squamous cell carcinoma of the esophagus. Int $\mathrm{J}$ Radiat Oncol Biol Phys 57 : 425-433, 2003

2）日本食道疾患研究会編：食道癌治療ガイドライ ン. 金原出版, 東京, 2002, p32

3) Ishikura $\mathrm{S}$, Nihei $\mathrm{K}$, Ohtsu $\mathrm{A}$, et al : Long-term toxicity after definitive chemoradiotherapy for squamous cell carcinoma of the thoracic esophagus. J Clin Oncol $21: 2697-2702,2003$ 